\title{
UDC 070:025.7/.9(594)
}

\section{ZAIN Labibah}

Department of Library and Information Science, UIN Sunan Kalijaga Yogyakarta (Yogyakarta, Indonesia), e-mail: labibah@uin-suka.ac.id, ORCID 0000-0002-6772-5722

\section{ADIBA Syifa}

Research School of Humanities \& Arts, College of Arts and Social Sciences, Australian National University (Canberra, Australia), ORCID 0000-0003-3410-2032

FARADISE Akmal

Department of Library and Information Management, Universitas Gadjah Mada (Yogyakarta, Indonesia), ORCID 0000-0001-7109-8015

PRABOWO Thoriq T.

Department of Library and Information Science, UIN Sunan Kalijaga Yogyakarta (Yogyakarta, Indonesia), ORCID 0000-0001-8196-7958

\section{PRESERVING INDONESIAN JOURNALISM HISTORY AT NATIONAL PRESS MONUMENT}

Objective. The National Press Monument is a part of the Indonesian Ministry of Communication and Information (KOMINFO) which has the sole responsibility of developing the communication and information sectors of the government including media and journalism. This research explains the preservation process of the Indonesian Journalism newsprint implemented at the National Press Monument. The purpose of this study is to give an overview of the importance of Indonesian Journalism newsprint to users of the National Press Monument. Indonesian Journalism newsprint is a vital source containing Indonesia's press history and information about the Indonesian Journalist Association before Indonesia gained its independence. National Press Monument collects and preserves old Indonesian newsprint and journals on various subjects. Methods. The qualitative approach and observation methods are used for this research. The observation method is used to focus on the preservation practices. Alongside the observation, the technique is the application of in-depth interviews. These methods are used to explain the processes of newsprint preservation. Results. The results of the study have found that National Press Monument used four approaches to preserve newsprint material: preventive, curative, restorative, and digitalization. Preventive action is carried out by controlling temperature, humidity, light, preventing human-caused damage and conducting bookbinding action. The curative operation was done by fumigation using Sulfuryl Fluoride (S02F2). The restorative step is done by connecting parts of torn/perforated paper, and repairing damaged binding. Finally, digitalization. National Press Monument also developed a new method to preserve newsprint material which is called freezing. This new method is aimed to protect the manuscript from any harmful organism. Conclusions. These methods can also be used in libraries. The National Press Monument not only contributes to preserving newsprint material in Indonesia but also to develop new ways in protecting the manuscripts through various policies.

Keywords: Newsprint; Magazine; Preservation; Conservation; National Press Monument

\section{Introduction}

Print media is one of the primary sources and mediums to disseminate information to the public, including using libraries. Ever since before Indonesia gain its independence, print mass media has had a vital role in summarizing and providing valuable information about issues in Indonesia. The proliferation of technology has altered the way people access information. More people are keen on searching the information through their devices. Despite those conditions, print media still exist in this digital era. This is because there is substantial evidence that can be traced in the print media. However, the storage management of old print media format sometimes exacerbates its physical condition. For example, a newspaper became one of the increasingly fragile materials due to poor storage. This condition is unfortunate as the old newspaper has significant value in historical aspects and essential information. Digitalization can 
be the answer to cope with this problem. Thus, National Press Monument (NPM) exists to safeguard the information regarding the print media, both its history and object.

National Press Monument (NPM) is one of the institutions under the Directorate General of Information and Public Communications of The Indonesian Ministry of Communication and Information (KOMINFO) which has a vision and responsibility as a national press reference. NPM has to perform documentation and conservation of historical printed media evidence throughout Indonesia, from before Independence Day until the present time. The entire collection will also be disseminated to the society as a supporting media for nation and character building as well as a scientific tourist attraction in the press field press and community literacy (Monumen Pers Nasional [National Press Monument], 2019).

Sri Mangkunegara VII established NPM on December 21, 1918, which was named Gedung Sasanasuka or Societeit Mangkunegaran. Then, NPM became one of the cultural heritage places because of its historical value. This place became the location of a journalist conference called Konferensi Wartawan Seluruh Jawa, the forerunner to the establishment of the Indonesian Journalist Association (PWI) on 9 February 1946. After that, NPM became a place for people to know the history and development of the Indonesian press. NPM has a museum that contains anything related to the Indonesian press; statues of Indonesian press pioneers, a diorama of Indonesian press development, journalist's tools (typewriter, photographs, recorders, and clothes), and press images. There is a library under NPM that provides a collection of books in the press, communication and information, and publications of other disciplines. The visitors are also provided access to e-paper and print newspapers, from an old version to the newest version (Monument Press National [National Press Monument], 2017).

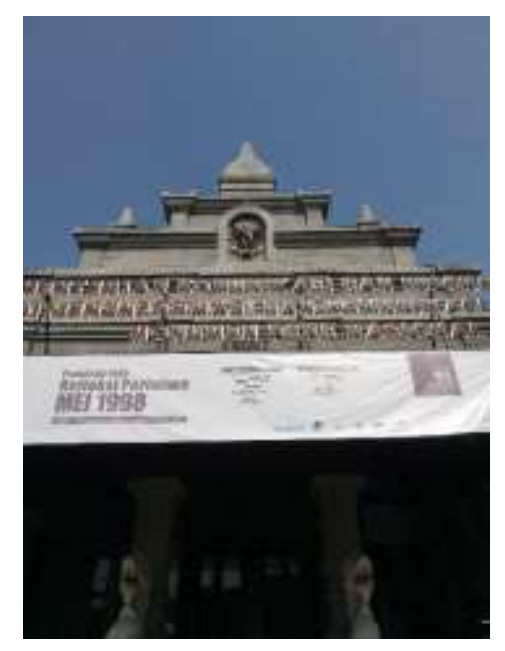

Fig. 1. National Press Monument building

NPM has various collections ranging from magazines, bulletins, tabloids, books, and newspapers. The classification of the collection is divided into two; magazines (consisting of magazines and bulletins) and newspapers (consisting of newspapers and tabloids). NPM has 526 newspaper titles and 405 magazine titles. The oldest newspaper collection dates from 1816 (Java Gou Gazette), while the oldest magazine was from 1904 named Tjehaja Sijang (Mediari Yulian P 2018, pers. comm. 30 May). NPM conducts preservation to the entire collection. This activity is carried out by the Conservation and Preservation Section (Supardi 2018, pers. comm. 21 May). It can be seen that NPM has a vital role to maintain and distribute information about the Indonesian press; history and development. Various collections of mass media within the printed 
format in NPM (especially, newspapers) need to be maintained physically and/or the content. Handling the proper preservation and conservation of printed media collection will make the object remain accessible by the community as reference material.

The purpose of this research is to know how the process of preservation and conservation of printed media collections conducted by NPM against mass media collection. To perform this research, the researchers use direct observation and interviews. Observations are needed to see what happened during the fieldwork. We visited NPM to know the process of preservationconservation and to know the condition of storage collection. Interviews were conducted to find out more about how a method was formulated and how a technique was done. There are four key informants in the interview section, namely the head of the Preservation and Conservation section, two conservators, and a person from the digitalization section who is also an initiator of the freezing method. The data from these four informants are being used to find out the NPM profiles in general; policies and techniques for preservation-conservation.

\section{LITERATURE REVIEW}

\subsection{Newspaper}

Currently, newspapers are one of the important sources of information for scholars and researchers. Newspapers contain information from day to day that is not included in other information media (Thabakgolo \& Jorosi, 2014). Local and national newspapers have the potential not only to present actual information, in a broader perspective, but newspapers will also preserve knowledge, history, and local wisdom. (Selvelli, 2018). However, newspaper preservation was less of a focus for many information agencies until the late 19th century. Many people agree that institutions related to newspapers, such as newspaper publishers and museums about newspapers have a responsibility to do so (Moore \& Bonnet, 2015).

\subsection{Preservation}

One of the things that threaten access to information is the lack of information itself. In the context of communication, information can be corrupted, distorted, or can be lost altogether. Information distortion usually occurs due to a lack of enthusiasm to confirm the information received; whereas, loss of information usually occurs due to the inability to maintain the source of the information itself. Information management institutions such as libraries must be sensitive to this kind of issue (Prabowo \& Manabat, 2019).

Preservation efforts related to newspapers are also developing along with technological developments, starting from binding to digitization (Ifijeh, Iwu-James, \& Osinulu, 2015). The majority of preservation efforts made on newspapers are digitization (Krahmer \& Phillips, 2014). Many digitization efforts, such as scanning original documents, have been carried out. Preservation with this method requires a cost that is not cheap (Nilsson, 2012). The collaboration will help the preservation agenda. The partnership is something that needs to be considered in the preservation and conservation planning of newspapers (Krahmer, 2016).

\subsection{Conservation}

Paper is the most common substrate for recording information, and if manufactured properly, can be very resistant to aging. The target of conservation is to slow down the deterioration and extend the useful life of the artifact. The main paper conservation methods are classified in the following categories: preparation of the intervention, disinfestation and disinfection/sterilization, surface/dry cleaning, wet cleaning, chemical stabilization, paper repairs, consolidation, and strengthening (Alexopoulou \& Zervos, 2016). The types of objects treated by the majority of organizations practicing paper conservation consist mainly of 
manuscripts, archival material, books, maps, topographical drawings, and photographic material. The great majority of them implement at least one of the methods (Alexopoulou \& Zervos, 2016).

As a paper-based collection, newspapers have several characteristics and similarities with manuscripts like parchment. Due to the vulnerability of its materials, newspapers should be treated in a proper way. Department of Culture, Ministry of Tourism and Culture, Government of India has a "Basic Minumum Standard for Conservation of Manuscript" that can be applied for old newspaper conservation too. A damaged newspaper should handle carefully. Firstly, record the damage of the newspaper and discuss it will the conservation team or to whom it may concern. Secondly, plan a step-by-step conservation treatment with all the best tools and materials available. And then follow the policy with minimum intervention if needed. Lastly, document the conservation process detailly (National Mission for Manuscripts, n.d.).

\subsection{Indonesian Journalism History}

Mass media is a tool or means of delivering information to the wider community through mass media such as print and electronic media. Mass media can be divided into three types, namely electronic media such as television and radio, print media, namely newspapers and magazines, and finally, online media such as the internet, streaming TV, and information that can be accessed via the internet (Putra, 2019). In order to survive in the digital era, the print mass media must maintain its integrity and credibility. To do that, journalists must work professionally (Kusuma, 2016).

'National Press Monument' main building was constructed in 1918 by Mangkunegara VII order. The building was designed by Mas Aboekasan Atmodirono as a town hall and conference venue. Firstly known as 'Societeit Sasana Soeka'. Solosche Radio Vereeniging, the first public radio operated by Indonesia, initiate here and also Indonesia Journalist Association was established at the Societeit Sasana Soeka. On May, 22nd 1956 established a foundation that protect the national press. This foundation was initiated by Roshan Anwar, B. M. Diah dan S. Tahsin. 15 years later, the foundation planned to build a physical building as mentioned by the information minister, Budiarjo in 1971. 'National Press Monument' named and legalized in 1973, and first opening in Pebruary, 9th 1978 by Soeharto (second President of Indonesia) (Sistem Registrasi Nasional Cagar Budaya, 2021).

Independent Journalist Alliance (AJI) assembled as a resistance movement from the Indonesian press community to counter authoritarianism of the 'New Order' era in Indonesia. Freedom of speech and expression were oppressed during the 'new order' era, and finally free in the 'Reformation' era with an increase of publication. The movement started on June, 21st 1994 after a bridle incident of several mass media. Now, AJI has a commitment to fight for public rights on information and freedom of pers (Aliansi Jurnalis Independent, 2019).

Inlandsche Joernalisten Bond (IJB) is the first Indonesian journalist organization and it was formed in 1924. This organization was established for sake of struggle and profession. A year later, on February 9, 1946, the Association of Indonesian Journalists (PWI) was established as a national forum for journalists in the Indonesian press. Besides journalists and mass media, the press ecosystem needs advertising companies. Then the government regulate the Basic Provisions of the Press with made Law Number 21 of 1982 which designated The Association of Indonesian Advertising Companies (P3I) as a member of the national press organization. In 1954, Indonesian Advertising Bureau Association (PBRI) was established as a national organization in the advertising sector (PWI.or.id, 2019).

Journalism history in Indonesia doesn't only tell about the repression of freedom of speech but also struggle against colonial domination and to defend the proclamation. Press in 
Indonesia looks identical to struggle and national development. Then, on January 23, 1985, President Soeharto was correct to set February 9 as National Press Day (PWI.or.id, 2019).

Furthermore, regarding the preservation of the treasures of printed mass media that have historical value, related institutions such as libraries and museums must be more involved in preservation and conservation efforts. Museum institutions that manage information sources in the form of newspapers have a vital role in preservation action. The agency provides a variety of information needed by professional media (Sreekala \& Baby, 2019).

Indonesia's press history can divide into five periods (Hamson, 2019). 1) Press during the Dutch East Indies Period, 2) The Press of the Japanese Colonial Era (1942 - 1945), 3) Press in the Old Order Era (1957 - 1965), 4) Press in the New Order Era and The Pancasila Press, and 5) Press Reformation Era. Every period has several characters which differ from each other.

We can see that Press in the Dutch East Indies Era was started from 1744 until the early 19th century. It was beginning with the first publication of Bataviasche Nouvelles (Batavia News) on August, 7th 1744 (Taylor, 2009). One of the important person that time is RM Tirtoadisuryo, Chief editor of "Medan Prijaji". Medan Prijaji is was the first newspaper controlled by the natives and it cause press activity in Indonesia to increase (Hamson, 2019).

The Press of the Japanese Colonial Era lasted 1942-1945. Japanese colonial prohibited newspapers published during the Dutch colonial. Indonesian press not only has progressed in technical competence, but also the issuance of press issuance permits (Hamson, 2019).

Press in the Old Order Era happened from 1957 to 1965. The government oppressed the press and banning several newspapers can't be avoided. In this era, the government stated that freedom of speech and expression should have boundaries, which refers to nation base and public interest (Hamson, 2019).

As the longest governing years president, Soeharto had more approaches to oppress the pers. In the Soeharto era from 1966 to 1998, the press period can divide into New Order Era and The Pancasila Press era. Press in the New Order era gained more freedom in comparison to the older era (Suwirta, 2018). But, all mass media publications are under government supervision through the information department (Hamson, 2019). Then in the Pancasila Press era, the Soeharto government formulated the 'original' press system based on Siebert, Peterson, and Schramm categories which are included in the type of social responsibility. This concept labeling as development journalism, and also known as 'Development Press' or 'Pancasila Press' (Hamson, 2019). This system means to represent Pancasila as a national base in every particular pers activity (Rasid, 2011).

Last, Press Reformation Era. This era starts on May 21, 1998, according to the ruin of the New Order era. Since 1998, the national press regains enjoyed freedom of speech and expression. Many press publications or new newspapers, magazines, or tabloids emerged (Hamson, 2019).

\section{Methods}

This research employed a descriptive qualitative method using qualitative approaches. Bogdan and Biklen (1982, p. 27) said that qualitative research is descriptive data. The data collected is in the form of words or pictures rather than numbers. The researchers collected research data in the form of conversational fragments. Descriptive data were produced from analyzing the text based on in-depth interview activities, observation activities, written field notes, and information gathered from the documentation. These methods can also be used to explain the processes of preservation of newsprint in the collections of academic libraries. 
The research started gathering data using in-depth interviews followed by observation techniques. Four key persons were interviewed consisting of the head of the Conservation and Preservation Section, two NPM conservators, one person from the digitalization section, and finally the initiator of the freezing method. The observation was conducted to see the actual preservation process. Field notes were done to record what happened in the field.

The collected data were analyzed using content analysis to categorize the data, code data, and make descriptive findings. The research used Miles and Huberman to analyze and display research data.

\section{Results and Discussion}

\section{Collection of National Newspaper in NPM}

NPM collects many print media. The format is diverse from newspaper, magazine, tabloid, bulletin and book. The collections were collected from all over Indonesia in several ways; grants and purchases. NPM received print collections from the mass media that volunteered to give each of their publications, within an agreement. Collections from donations are also obtained from some prominent figures in the journalistic press or collectors who collect many old items. If mass media does not give away their free publications, NPM will buy them by subscription, such as once every two weeks or once a month (Mediari Yulian P 2018, pers. comm. 30 May). This condition is depending on how the mass media do the shipping method. NPM will also make purchases of collector's collections, although it is quite expensive.

One of the information sources that stores historical value is a national newspaper. By storing newspapers, NPM can map the development of the press in every region in Indonesia. This is because many important historical events are covered in the daily newspaper. On the other hand, the newspaper is still one of the important media of information for researchers to find the main reference about important events in the past. NPM collects many titles, from newspaper to magazine. For instance, Panorama magazine, Gadis, Nyota, and others. There are also Tthaja Hindia, Sumatra Courant, Republika, Kompas as newspaper formats. Those collections used local language or foreign language (Slamet Widodo 2018, pers. comm. 21 May).

A large amount of collection in printed media collected by NPM is almost directly proportional to the community's need to access the information. However, the physical state of the old newspaper is in fragile.

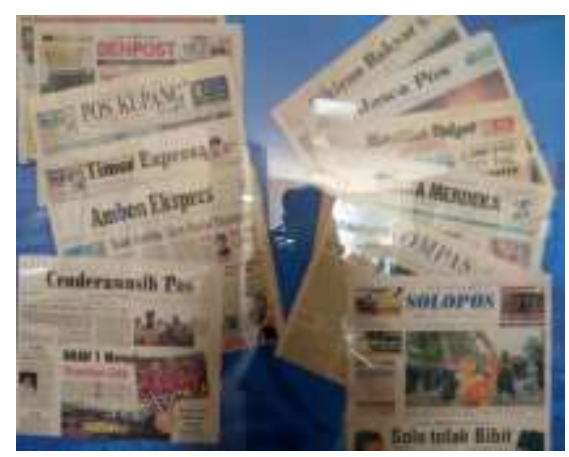

Fig. 2. Newspaper collections

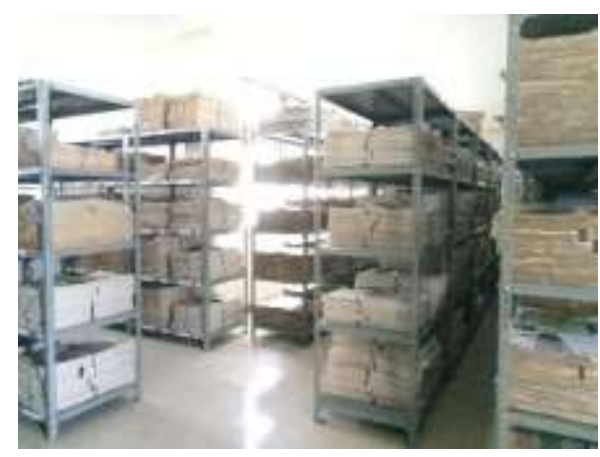

Fig. 3. Storage room 


\section{Preservation and Conservation Methods in NPM}

Hasenay and Krtalić (2010) provide two reasons why preserving newspaper is such a challenging task. First and foremost, the low quality of newspaper material. Secondly, the newspaper contains important information. Both combinations need to be maintained well in order to retrieve the information. Based on this condition, NPM does several actions to protect their collection.

Environmental Control. NPM has some storage space on the 2nd, 3rd, and 4th floors. These places are kept being cold in order to protect the physical collection (Mediari Yulian P 2018, pers. comm. 30 May).

Pest Management. Newspaper is a pest-prone media. The smell of newspaper can attract insects to come. Indeed, this condition can harm the collection. NPM uses some natural ingredients such as cloves and pepper to prevent the insects from going near the collection. Besides, the smell of the natural ingredients is friendlier to our sense of smell and health (Mediari Yulian P 2018, pers. comm. 30 May).

Storage Room. The storage space of digitized collection is outside of users' reach. This is because NPM wants to avoid undesirable actions and to ensure the health of the visitors. The storage room in NPM is not good enough for the user's health. Collections in the storage room can still be accessed for further research (Mediari Yulian P 2018, pers. comm. 30 May).

NPM performs preservation depending on the condition of the manuscript. Several approaches/methods have been done by NPM against preservation and conservation. Firstly, the preventive method. This step was done to prevent the physical collection from the deteriorating condition. The actions taken are to secure the collection with naptalin, camphor, cloves, and pepper. So that, the insects will not attack the collection. The area around the collection is also protected by mouse glue to trap the insects that roam around the collection (Rahayu Trisnaningsih 2018, pers. comm. 21 May). Secondly, the curative method. This method is selected if the collection has started to show lousy condition, but not yet in broken condition. An example of this state is when the paper turned yellow, moldy, and exposed to insulation. These three problems can be solved by using acetone (Rahayu Trisnaningsih 2018, pers. comm. 21 May). Thirdly, the restorative method. This step was done when the collection was already in damaged condition. To solve this problem, NPM patched the collection using Japanese tissue. But so far, NPM has not taken restorative measures against old newspaper collections because of limited facilities and human resources (Rahayu Trisnaningsih 2018, pers. comm. 21 May). Restorative actions are carried out on the book collection within NPM Library (Mediari Yulian P 2018, pers. comm. 30 May). Fourthly, digitalization. Principally, the entire collection in NPM will be digitized (Supardi 2018, pers. comm. 21 May). In general, collections that are classified in a very fragile condition and have important information will be prioritized to digitize first rather than other material. Media transfer was done by photographing each collection using DSLR cameras. Furthermore, photos are processed on the computer and will be edited (if needed), such as cropping and enhancing. Lastly, freezing. This method is actually a part of the restorative method, and the final step before a collection is being stored in a storage place. The freezing method is the initiative of Rahayu Trisnaningsih and has been done since 2015. In principle, the freezing process is 'treating' collections like food. Both food and paper contain cellulose. So that, the collection can last longer if using the freezing method. There are two freezers to freeze the collection, and it is actually an ordinary freezer/food freezer (Rahayu Trisnaningsih 2018, pers. comm. 21 May). The collections will be cleaned first from dust and other dirt using a vacuum machine before the conduction freezing method. Next, the collection is put into special plastic with food-grade quality. After that, the collection will be stored in the freezer within minus twenty degrees Celsius and froze for 14 days period. Finally, the collection 
will be stored in the storage room. Collections stored in the storage room are the collection that has been digitized. Currently, NPM is freezing the small collection of magazines. NPM still has the challenge to freeze newspaper format due to the difficulties in finding the special plastic. NPM is still in search of plastic wrap to freeze the newspaper (Rahayu Trisnaningsih 2018, pers. comm. 21 May).

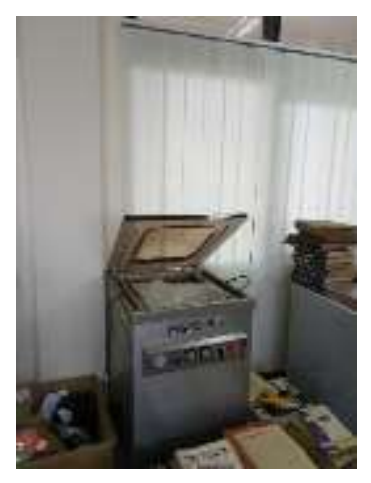

Fig. 4. Vacuum machine

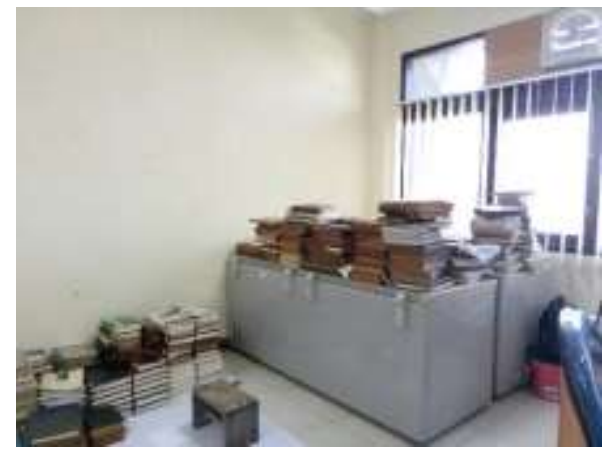

Fig. 5. Freezer

Unfortunately, NPM has several problems while conducting those methods. The lack of budget, human resources, $\mathrm{s}$, and tools is probably the most notable problem. This condition will lead to other problems, such as collection restoration and freezing newspaper collection problems. NPM has not yet done the collection restoration due to a limited budget. The freezing method cannot be done on newspaper material because they did not have the resources to help them to do the freezing. This, of course besides their hardship in finding the plastic to wrap the newspaper material. Another problem to point out is that NPM did not have a written policy about preservation and conservation. In order to conduct the preservation and conservation method, the officer only did the program because it is her desire. This condition may seem trivial. However, if NPM did not have the written policy, it is hard to trace the previous work. As a worse case, if the officer retired in the future and there are new people to replace his/her place, they have no guidelines on doing the preservation and conservation.

\section{Conclusions}

According to this study, five methods are being used by NPM to preserve and conserve the collection. These methods can also be used in libraries. Three methods, namely preventive, 
curative and restorative methods are being applied depending on the collection condition. While digitalization was done to preserve the content within the material. Freezing is being categorized as a preventive technique. This is because the method saves the physical collection that is already being digitalized. There are several obstacles faced by NPM about the preservation and conservation program. In order to cope up with the problem, there are several recommendations for NPM. The most important thing to do is formulate a policy about preservation and conservation. This condition will help the conservators to work more efficiently. Not only that, we can also see the progress of the program and make an evaluation. So that, the program will be sustainable in the future. The policy will also help NPM to analyses technical constraints and solve them immediately. On the other hand, NPM also can work with several parties to overcome the funding, human resources, and infrastructure problem.

\section{REFERENCES}

Alexopoulou, I., \& Zervos, S. (2016). Paper conservation methods: An international survey. Journal of Cultural Heritage, 21, 922-930. doi: https://doi.org/10.1016/j.culher.2016.04.001 (in English)

Aliansi Jurnalis Independen. (2019, July 16). Sejarah Aliansi Jurnalis Independen. Aliansi Jurnalis Independen. Retrieved from https://aji.or.id/read/sejarah/1/sejarah-aliansi-jurnalisindependen.html (in English)

Bogdan, R. C., \& Biklen, S. K. (1982). Qualitative research for education: An introduction to theory and methods. Boston: Allyn and Bacon, Inc. (in English)

Hamson, Z. (2019). Pers dalam lintasan peradaban. CV Tohar Media. (in Indonesian)

Hasenay, D., \& Krtalić, M. (2010). Preservation of newspapers: Theoretical approaches and practical achievements. Journal of Librarianship and Information Science, 42(4), 245-255. doi: https://doi.org/10.1177/0961000610380818 (in English)

Ifijeh, G., Iwu-James, J., \& Osinulu, I. (2015). From binding to digitization: issues in newspaper preservation in Nigerian Academic Libraries. Serials Review, 41(4), 242-249. doi: https://doi.org/10.1080/00987913.2015.1103153 (in English)

Krahmer, A. (2016). Digital newspaper preservation through collaboration. Digital Library Perspectives, 32(2), 73-87. doi: https://doi.org/10.1108/DLP-09-2015-0015 (in English)

Krahmer, A., \& Phillips, M. (2014). Texas newspaper PDF preservation: A low-cost solution with tremendous value. IFLA WLIC 2014, 1-18. Retrieved from http://ifla-test.eprintshosting.org/id/eprint/1033/ (in English)

Kusuma, S. (2016). Posisi media cetak di tengah perkembangan media online di Indonesia. Jurnal InterAct, 5(1), 56-71. doi: https://doi.org/10.36388/ia.v5i1.772 (in Indonesian)

Monumen Pers Nasional (National Press Monument). (2017). Buku Panduan Pengunjung Monumen Pers Nasional. [Guide book for the National Press Monument's visitors]. (in Indonesian)

Monumen Pers Nasional (National Press Monument). (2019, May 15). Tentang kami-Monumen Pers Nasional. [About us - National Press Monument]. Retrieved from https://mpn.kominfo.go.id/index.php/project/tentang-kamii/ (in Indonesian)

Moore, J.E., \& Bonnet, J. L. (2015). Survey finds differences on preserving born-digital news. Newspaper Research Journal, 36(3), 348-362. doi: https://doi.org/10.1177/0739532915600748 (in English)

National Mission for Manuscripts. (n.d.). Basic minimum standards for conservation of manuscripts. Retrieved from https://namami.gov.in/sites/default/files/conservation.pdf (in English) 
Nilsson, P. (2012). Newspaper digitization in Sweden. Microform \& Digitization Review, 41(3-4), 126128. doi: https://doi.org/10.1515/mir-2012-0020 (in English)

Prabowo, T. T., \& Manabat, A. R. (2019). Gethok Tular, traditional knowledge preservation method: opportunities and challenges. Proceedings of Adab-International Conference on Information and Cultural Sciences, 1, 45-54. Retrieved from https://digilib.uin-suka.ac.id/id/eprint/37732/ (in English)

Putra, R. A. (2019). Tantangan Media Massa Dalam menghadapi era disrupsi teknologi informasi. JUSIFO (Jurnal Sistem Informasi), 5(1), 1-6. doi: https://doi.org/10.19109/jusifo.v5i1.5003 (in Indonesian)

PWI.or.id. (2019, July 16). Sekilas sejarah pers nasional. Retrieved from https://www.pwi.or.id/detail/26/Sekilas-Sejarah-Pers-Nasional (in Indonesian)

Rasid, A. (2011). Pola interaksi pers, pemerintah dan masyarakat dalam membentuk sistem pers Pancasila: suatu analisis retrospektif. Sosiohumaniora, 13(2), 189. doi: https://doi.org/10.24198/sosiohumaniora.v13i2.5516 (in Indonesian)

Selvelli, G. (2018). The role of the newspaper Parekordzagani Tzain and its related institutions in the preservation of language and identity in the armenian community of Plovdiv. Bulletin of the Transilvania University of Braşov, Series IV: Philology \& Cultural Studies, 11(1), 199-222. (in English)

Sistem Registrasi Nasional Cagar Budaya. (2021, August 15). Monumen Pers Nasional. Retrieved from http://cagarbudaya.kemdikbud.go.id/cagarbudaya/detail/PO2015121500015/monumen-persnasional (in Indonesian)

Sreekala, P. K., \& Baby, M. D. (2019). Digital archiving and access to print media resources: A study among leading malayalam newspaper libraries in Kerala. Asian Journal of Information Science and Technology, 9(3), 19-24. doi: https://doi.org/10.51983/ajist-2019.9.3.293 (in English)

Suwirta, A. (2018). Pers dan kritik sosial pada masa orde baru: studi kasus pers mingguan mahasiswa indonesia di Bandung, 1966-1974. Mimbar Pendidikan, 3(2), 113-136. doi: https://doi.org/10.17509/mimbardik.v3i2.13949 (in Indonesian)

Taylor, J. G. (2009). The social world of Batavia: Europeans and Eurasians in colonial Indonesia (2nd ed.). The University of Wisconsin Press. (in English)

Thabakgolo, M., \& Jorosi, B. N. (2014). Newspaper preservation at Botswana's legal repositories. Journal of the South African Society of Archivists, 47, 61-76. doi: https://doi.org/10.4314/jsasa.v47i0 (in English)

\section{ACKNOWLEDGEMENT}

Authors acknowledge the National Press Museum as the main informant of our research. It is highly impossible for us to finish this research without the contribution of Mrs. Mediari Yulian P. as the head of Conservation and Preservation Section, Mr. Supardi and Mr. Slamet Widodo as NPM conservators and lastly, Ms. Rahayu Trisnaningsih from digitalization section as well as the initiator of the freezing method. 
ZAIN Labibah

Департамент бібліотечної та інформаційної науки, UIN Сунан Каліджага Джокьякарта (Джокьякарта, Індонезія), e-mail: labibah@uin-suka.ac.id, ORCID 0000-0002-6772-5722

ADIBA Syifa

Дослідницька школа гуманітарних наук та мистецтв Коледжу гуманітарних та соціальних наук Австралійського національного університету (Канберра, Австралія),

ORCID 0000-0003-3410-2032

FARADISE Akmal

Департамент бібліотечного та інформаційного менеджменту, Universitas Gadjah Mada

(Джокьякарта, Індонезія), ORCID 0000-0001-7109-8015

PRABOWO Thoriq T.

Департамент бібліотечної та інформаційної науки, UIN Сунан Каліджага Джокьякарта

(Джокьякарта, Індонезія), ORCID 0000-0001-8196-7958

\section{ЗБЕРІГАННЯ ІСТОРІЇ ІНДОНЕЗІЙСЬКОЇ ЖУРНАЛІСТИКИ В НАЦІОНАЛЬНОМУ ПАМ'ЯТНИКУ ПРЕСІ}

Мета. Національний пам'ятник пресі є частиною Міністерства зв'язку та інформації Індонезії (КОМІНФО), яке несе виняткову відповідальність за розвиток комунікаційних та інформаційних секторів уряду, включаючи засоби масової інформації та журналістику. Це дослідження пояснює процес збереження газетного фонду індонезійської журналістики, що зберігається у Національному пам'ятнику пресі. Мета цього дослідження - дати огляд важливості газетного фонду індонезійської журналістики для користувачів Національного пам'ятника пресі. Газетний фонд індонезійської журналістики $є$ важливим джерелом інформації про історію преси Індонезії та інформації про Асоціацію індонезійських журналістів до здобуття Індонезією незалежності. Національний пам'ятник пресі збирає та зберігає старий індонезійський газетнийфонд та журнали різної тематики. Методика. У дослідженні використовуються якісний підхід та методи спостереження. Метод спостереження використовується, щоб зосередитись на методах збереження. Поруч із технікою спостереження застосовується глибинне інтерв'ю. Ці методи використовуються для пояснення процесів збереження газетного фонду. Результати. Результати дослідження показали, що National Press Monument використовує чотири підходи для збереження газетних матеріалів: профілактичний, лікувальний, відновлювальний та оцифрований. Профілактичні дії здійснюються шляхом контролю температури, вологості, освітлення, запобігання пошкодженням з вини людини та проведення палітурних робіт. Лікувальнана операція проводилася шляхом фумігації з використанням сульфурилфториду (S02F2). Відновлювальний етап виконується шляхом з'єднання частин розірваного/перфорованого паперу та відновлення пошкодженої палітурки. Зрештою, цифровізація. Національний пам'ятник пресі також розробив новий метод збереження газетного фонду, який називається заморожуванням. Цей новий метод спрямований на захист рукопису від будь-яких шкідливих організмів. Висновки. Ці методи також можна використовувати у бібліотеках. Національний пам'ятник пресі не тільки сприяє збереженню газетних матеріалів в Індонезії, але й розробляє нові засоби захисту рукописів за допомогою різних заходів і методів. Ключові слова: газетний фонд; журнал; зберігання; консервація; Національний пам'ятник пресі

Received: 22.07 .2021

Accepted: 19.11.2021 